rev.relac.int.estrateg.segur.8(2):63-93,2013

\title{
VIOLENCIA POLÍTICA EN CHILE ENTRE EL PUEBLO MAPUCHE Y EL GOBIERNO DEL PRESIDENTE RICARDO LAGOS*
}

\author{
Javiera Donoso Jiménez ${ }^{* *}$
}

\section{RESUMEN}

Con el retorno de la izquierda socialista al Palacio de la Moneda se esperaba que la democracia se consolidara definitivamente en Chile. Sin embargo, los métodos represivos y violentos utilizados por el Estado perduraron y se perpetuaron como mecanismo de control social. Durante el gobierno de Ricardo Lagos, la protesta social Mapuche fue reprimida, perseguida y criminalizada, tras el argumento de la protección a la gobernabilidad política y la institucionalidad democrática. La metodología que se utilizó se basa en la revisión de prensa para registrar los episodios de violencia provenientes del pueblo Mapuche y del Estado chileno. Con esa información se comparó el uso de la violencia entre ambos actores. El principal resultado encontrado es que el Estado chileno mantiene el control y monopolio de la violencia en el país,

* Investigación inédita resultado de la estancia posdoctoral 2012-2013 realizada para la Dirección General de Asuntos del Personal Académico de la Universidad Nacional Autónoma de México, adscrita al Centro de Estudios Sociológicos de la Facultad de Ciencias Políticas y Sociales de la Universidad Nacional Autónoma de México.

** Investigadora invitada por la Dirección General de Asuntos del Personal Académico -DGAPA- en la Facultad de Ciencia Política y Sociales Universidad Nacional Autónoma de México.

Comentarios a: jadonosoj@gmail.com 
siendo la violencia represiva del Estado siempre superior a la proveniente de la protesta Mapuche. La criminalización de la protesta Mapuche se logra de manera eficiente y efectiva gracias a las reformas que experimentó el poder judicial, lo que permitió enjuiciar y encarcelar a la población en conflicto bajo la figura de terrorismo.

Palabras clave: Gobierno de Ricardo Lagos, violencia política, represión estatal, protesta social, pueblo Mapuche

\title{
POLITICAL VIOLENCE IN CHILE BETWEEN THE MAPUCHE NATION AND PRESIDENT RICARDO LAGOS' GOVERNMENT
}

\begin{abstract}
The return of the socialist left to the Palacio de la Moneda in Chile brought the hope that democracy would at last be consolidated in Chile. However, the repressive and violent character of the Chilean State persisted and endured as a mechanism of social control. During Ricardo Lagos'government, the social protest of the Mapuche was repressed, persecuted and criminalized, using as argument the need for protection to political governability and to the democratic institutions. The methodology we used is based on the review of newspaper articles that report the episodes of violence from the Mapuche and from the Chilean State; this information allowed us to compare the intensity of violence between both parties. The most significant results we found, were that the Chilean State maintains control and monopoly of violence in the country, and the repressive State violence always surpasses that of the Mapuche. The criminalization of the Mapuche protest is efficient and effective thanks to the reforms on the judicial system, which allows judging and incarcerating the people in conflict under a treatment given to terrorists.
\end{abstract}

Keywords: Ricardo Lagos' government, political violence, state repression, social protest, Mapuche nation.

\section{VIOLÊNCIA POLÍTICA NO CHILE ENTRE O POVO MAPUCHE E O GOVERNO DO PRESIDENTE RICARDO LAGOS}

\section{RESUMO}

Com o retorno da esquerda socialista ao Palacio de la Moneda era de se esperar que a democrática se consolidaria de forma definitiva no Chile. No entanto, o âmbito repressivo e violento do Estado persistiu e se perpetuou como mecanismo de controle social. Durante o governo de Ricardo Lagos, o protesto social Mapuche foi reprimido, perseguido e criminalizado sob o argumento de uma proteção da governação política e da institucionalidade democrática. 
A metodologia utilizada está baseada na revisão da imprensa para registrar os casos de violência procedente do povo Mapuche e do Estado chileno. Com esta informação se comparou o uso da violência entre os dois atores. O principal resultado é que o governo chileno mantém o controle e monopólio da violência no país, sendo a violência repressiva do Estado sempre maior do que a do protesto Mapuche. A criminalização do protesto Mapuche é alcançada de forma eficiente e efetiva graças às reformas vividas pelo Poder Judiciário, que permitiu processar e encarcerar as pessoas em conflito sob a acusação de terrorismo.

Palavras-chave: governo de Ricardo Lagos, violência política, repressão estatal, protesto social, povo Mapuche.

\section{INTRODUCCIÓN}

En el año 2000 la izquierda chilena retoma el poder político al ocupar nuevamente el sillón presidencial. El ascenso como jefe de Estado del socialista Ricardo Lagos Escobar (2000-2006) venía apoyado en la esperanza de conseguir definitivamente la consolidación democrática y transportar a Chile a la igualdad y justicia social que había abandonado tras la instauración del neoliberalismo económico.

La consolidación democrática implicaría superar el pasado autoritario y violento, para reemplazarlo por espacios de participación y empoderamiento ciudadano. Si bien es cierto que hubo algunos avances en esta búsqueda, también hubo continuidad en las prácticas autoritarias y violentas.

El pueblo Mapuche fue uno de los grupos ciudadanos que vivió en carne propia la violencia estatal durante el gobierno de Ricardo Lagos, como consecuencia de su resistencia histórica que buscaba impulsar una nueva militancia Mapuche, y fomentara la protesta e insurgencia de su gente en pro de la restitución de sus derechos ancestrales.

Esta rebeldía fue liderada principalmente, durante el gobierno de Ricardo Lagos, por la Coordinadora de Comunidades en Conflicto Arauco Malleco (CAM). La CAM articuló y focalizó sus acciones violentas de protesta en contra de la propiedad privada de grandes terratenientes y empresas forestales instaladas en territorio Mapuche.

Estas acciones se sintetizaron en un discurso radical de reivindicación etnopolítica que tiene como objetivo final el reconocimiento como nación del pueblo Mapuche para así asegurar la recuperación de su territorio y su autonomía.

Por lo anterior, el Estado chileno decidió hacer valer la legitimidad y monopolio del uso de la violencia en contra de la ciudadanía movilizada, utilizando los aparatos represivos para contener 
la protesta y resguardar el orden público, siendo la persecución y disuasión policial el método utilizado con mayor frecuencia, complementado con la criminalización de la protesta a través del acoso judicial y penal que terminó con el encarcelamiento de los involucrados bajo la figura de terroristas.

Es precisamente este tema, la violencia política, el que será tratado en este artículo, donde se registraron e identificaron todos los eventos de violencia provenientes tanto del Estado como del pueblo Mapuche, con el objetivo de contrastarlos y compararlos en intensidad y gravedad.

\section{MARCO TEÓRICO}

Esta investigación está basada en el estudio de los repertorios e intensidad de los tres tipos de violencia (estructural, simbólica y física /represiva) que surgen como estrategia para resolver los conflictos que se suceden dentro del sistema político entre sociedad civil, actores del mercado y Estado.

La violencia estructural la ejerce y practica el Estado y el mercado, y la sufre la sociedad civil; la violencia simbólica la practican y sufren los tres actores; y la violencia física es expresada por la sociedad civil a través de la protesta social violenta y por el Estado a través de sus aparatos represivos.

La violencia política se entenderá como un elemento constituyente de la práctica política, ya que se encuentra presente en el ejercicio del poder político de todos los actores. Tal como lo plantea Carl Schmitt en su escrito El concepto de lo político, la violencia es parte fundamental del Estado y la política, ya que se sustenta en la idea de que existen "amigos" y "enemigos".

Schmitt es claro al expresar que los enemigos del Estado deben ser otros Estados, de las mismas condiciones y fuerza que les permitan enfrentarse en una eventual guerra. El liberalismo ha tratado de menguar esa imagen, presentado al Estado no como un aparato pensado para hacer la guerra, sino como un órgano regulador y garante del orden de la vida de las personas en sociedad.

Así surge la idea y concepto del Estado de derecho, que sustituye la política por la ética y el Estado por la economía. El Estado de derecho es liberal, y además es aquel Estado que busca proteger el derecho privado, por lo que el Estado se somete a las necesidades y requerimientos del mercado. El Estado de "derecho", se entiende como: el "derecho privado", mientras que el de la propiedad privada constituye el centro del globo cuyos polos -ética y economía- no son sino las irradiaciones contrapuestas de ese centro (Schmitt, 1932, p. 92).

El uso de la violencia en la política está incorporado por el Estado como un instrumento de control social y dominación, la que además se encuentra, hasta cierto punto, legitimada y justificada a 
través del derecho y las normas legales; pero también institucionalizada por medio de los aparatos represivos y militares del Estado:

Una asociación de dominación con carácter institucional que ha tratado, con éxito, de monopolizar dentro de un territorio la violencia física legítima como medio de dominación y que, con este fin ha reunido todos los medios materiales en manos de su dirigente y ha expropiado a todos los funcionarios estamentales que antes disponían de ellos por derecho propio, sustituyéndolos con sus propias jerarquías supremas (Weber, 1997, p. 92).

La institucionalización de estas formas de control se concreta gracias al establecimiento de "la legitimidad basada en la 'legalidad', en la creencia en la validez de preceptos legales y en la 'competencia' objetiva fundada sobre normas racionalmente creadas" (Weber, 1997, p. 87). De acuerdo a esto, se puede afirmar que el Estado crea leyes que facilitan la alienación y automatización de la población, cumpliendo así un rol restrictivo y supervisor de los ciudadanos.

Cuanto más se burocratice la vida pública, tanto mayor será el atractivo por la violencia. En una burocracia totalmente desarrollada, no queda nadie con quien discutir, nadie con quien presentar las quejas, nadie sobre quien ejercerse la presión del poder. La burocracia es una forma de gobierno en que todos quedan privados de libertad política, del derecho de actuar: pues el Gobierno de Nadie no es el gobierno, donde todos somos igualmente impotentes (Arendt, 1970, p. 72).

El Estado, al tener dominado el entorno y establecidas las alianzas de protección, debe preocuparse del orden interno, por lo cual comienza a inculcar una identidad común para sus ciudadanos. Ésta se sustentará en imágenes, códigos legales, educación, festividades, entre otras, las cuales pretenden construir un tipo de ciudadano modelo, que apruebe y comulgue con las acciones del Estado porque lo sentirá como parte de su propio ser.

Estos valores están inspirados en los fundamentos que movilizaron las luchas modernizadoras, promesas que sumadas al derecho de justicia, propiedad privada y vida, se expresaron e institucionalizaron en las constituciones nacionales buscando como resultado el compromiso y enajenación de las masas a través del derecho. Este derecho se configuró como un discurso oficial al que todos los ciudadanos debían adscribirse, lo que proporcionaría su apoyo y validación o sumisión definitiva, entregando el rol al Estado de proteger y velar por estos principios.

La mayor parte de esta violencia no ha tenido un carácter emancipador. Por el contrario, su propósito ha sido impedir la aniquilación de poder por grupos subalternos y reforzar el de los grupos dominantes, especialmente en aquellas circunstancias en que éste estaba siendo desafiado desde abajo (Kay, 2005, p. 65). 
El Estado también debió asumir la tarea de formar a sus ciudadanos como tales, por lo que se utiliza la violencia como instrumento de poder controlador y coercitivo que sustentaría el poder político. Paulatinamente, el sistema de justicia formal e imparcial (o como al menos se estableció oficialmente) es el que controla la vida de todos los ciudadanos, intimidándolos y acosándolos, reemplazando así el uso de la fuerza, pero teniendo el mismo sentido y significado, el control y constricción de la población.

De alguna forma, la propia estructura social genera sus métodos de vigilancia y castigo en las distintas facetas de la vida humana, construyendo enclaustramientos capaces de redirigir y perfilar el devenir vital del individuo, limitando sus posibilidades de elección y diseñando un estatuto ético ante el cual toda desviación sea punible; de esta forma el pensamiento individual es perfilado en el seno de la familia, la escuela, el ejército y el mundo del trabajo, y las desviaciones son castigadas con el reformatorio, el manicomio o la prisión. El individuo está pues condicionado por el poder, atrapado en una telaraña de la que no puede escapar (Gómez, 2001, p. 5).

El derecho no sólo se presenta como un instrumento de dominación y control social, sino también como una oportunidad de proporcionar justicia. Es innegable que la violencia estructural del Estado tiene ahí su origen, ya que a través de la impugnación del derecho, se construye la idea de lo bueno y lo malo, lo legítimo y lo ilegitimo, los patriotas y los antipatriotas.

Con el objetivo de identificar, encontrar, combatir y anular a sus enemigos, los Estados de corte liberal se ven impulsados a estigmatizar y tipificar acciones, grupos u organizaciones que se presenten como una amenaza, siendo un ejemplo de esto la relación del Estado chileno y el pueblo Mapuche.

El Estado chileno, actualmente, considera la protesta social -tanto pacifica como violenta del pueblo Mapuche- como un peligro a la estabilidad e institucionalidad política. Esta apreciación frente a la desobediencia ciudadana encasilló a la población Mapuche como enemigos del Estado, por lo que sus acciones comenzaron a ser perseguidas y procesadas judicialmente bajo ley de seguridad interior del Estado y la ley antiterrorista.

Quienes detentan el poder económico considerarán cualquier intento "extraeconómico" de modificar su posición de poder como un acto de violencia criminal e intentarán impedirlo (Schmitt, 1932, p. 1105).

Como diría Schmitt, un problema político se convierte en un problema económico, porque las demandas de los pobladores, en este caso Mapuche, están interviniendo con los intereses del mercado. Las demandas del pueblo Mapuche deben ser entendidas como una crítica directa al modelo de desarrollo y mercado que adoptó Chile, y la lucha fundada en el deseo por instaurar un modelo de desarrollo sustentable. 
La exclusión económica vinculada con el modelo de mercado instalado (neoliberal) plantea un escenario ideal para que se dé la violencia estructural. La debilidad de la democracia y las instituciones del Estado son factores clave para que la violencia estructural en el ámbito económico ejerza su poder.

Al existir debilidad democrática e institucional, los países sustentan su gobernabilidad, orden interno y satisfacción ciudadana en la estabilidad y bonanza económica.

La cooptación de la vida de los individuos y su entorno que ha logrado absorber el mercado en Chile instala una "nueva" forma de dominación que nace en la "sociedad de control" y que administra la vida del cuerpo social y del individuo en función de la productividad, habiéndose convertido en una herramienta indispensable para el desarrollo del sistema neoliberal.

De esta forma, se sostiene que la relación que el Estado de Chile mantiene con la protesta del pueblo Mapuche, forma parte de la dominación biopolítica del Estado, habiéndose convertido en un eje articulador capaz de garantizar el éxito en la hegemonía del sistema neoliberal en la región de La Araucanía (Villegas, 2009).

El Estado deja de ser Estado para convertirse en un instrumento del mercado, el cual declara como enemigos a los ciudadanos que combaten y contradicen su lógica de producción y funcionamiento. El procurar desmonetizar la discusión y el debate por parte de los Mapuche, implica politizar y reubicar la discusión del Estado liberal en el ámbito extraeconómico.

El Estado, por lo general, utiliza la violencia simbólica para reafirmar ante la gran masa su discurso hegemónico de poder e invalidar los discursos contrahegemónicos que puedan surgir en la contingencia política. Siempre el objetivo es mantener cooptada la opinión pública bajo los ideales del poder central y así reafirmar su poder a través de lo simbólico. Los símbolos más importantes que utiliza el Estado para asentar su poder desde sus génesis son los de la "identidad nacional", que logra convencer a las grandes masas de población haciéndolas sentir parte de este imaginario patriota.

La sociedad civil, por su parte, al no contar con el monopolio de la violencia, ni tener siquiera las mínimas posibilidades de acercarse -a la que tiene el Estado-, instrumentaliza el discurso como contrapeso al discurso hegemónico. El discurso contrahegemónico crea dinámicas diferentes a la hora de relacionarse entre la sociedad civil rebelde, el Estado y el mercado.

Al entender "simbólico" como opuesto a real y a efectivo, suponemos que la violencia simbólica sería una violencia puramente "espiritual" y, en definitiva, sin efectos reales. Esta distinción ingenua, típica de un materialismo primario, es lo que la teoría materialista de la economía de los bienes simbólicos, que intento elaborar desde hace muchos años, tiende a destruir, dejando que ocupe su espacio teórico la subjetividad de la experiencia subjetiva de las relaciones de dominación (Bourdieu, 2000, p. 50). 
La violencia política simbólica, si bien logra que el actor que la ejerce se posicione públicamente, sea reconocido por las otras fuerzas políticas y se quede en la retina de las masas, no consigue la obtención o tenencia del poder a través del terror que sugiere la muerte, sino por el contrario, se yergue como opción de violencia que anhela la protección de la vida de la mayoría y se limita a un tema discursivo y retórico, de amedrentamiento e intimidación, sin llegar al derramamiento de sangre o sacrifico de vidas en pos de la imposición de su postura.

Cuando se habla de violencia física/represiva se está haciendo referencia a un tipo de violencia que podríamos denominar como clásica, la que todos comprendemos y que a simple vista es reconocida por todos, institucionalizada y -en ocasiones- hasta aceptada.

El poder que adquiere el mercado en un Estado liberal como el chileno permite criminalizar a los opositores. La oposición Mapuche persigue reposicionar la discusión en el ámbito político, planteando la idea de que existen modelos de desarrollo alternativos al neoliberalismo económico.

La violencia física que se estudiará en esta investigación no es la que aspira a arrebatarle el poder al Estado y derrocarlo, sino la que se da a través de la protesta social. "Debe anotarse una diferencia entre la fuerza, que va hacia la autoridad y procura imponer una sumisión, y la violencia, que aspira a destruir dicha autoridad. A juicio suyo, el proletariado debe adueñarse de la fuerza como lo hizo la burguesía, utilizarla de igual modo de ésta." (Sorel, 1971:167).

La violencia física es ejercida por la sociedad civil como respuesta a la violencia estructural y simbólica que es ejercida por parte del Estado, siendo explosiva y capaz de canalizar las frustraciones de la población. La violencia física, por tanto, es un recurso de visibilización política que se incorpora en los repertorios de protesta social. La violencia tiene como principal objetivo instalar en la escena política los discursos, las demandas y las realidades de los rebeldes. "Es necesario reconocer que la utilización calculada de la violencia tiene a menudo, sino una perspectiva reformista admitida, sí, por lo menos, efectos reformistas" (Michaud, 1989, p. 64).

En ese sentido, la violencia física por parte de la sociedad civil en contra del Estado se manifiesta a través de repertorios como el enfrentamiento cuerpo a cuerpo con la policía o agentes del Estado; también se considerará como violencia física por parte de la sociedad el que genera daño a la propiedad pública o privada (quemas, barricadas, apedreos, etc.) en el contexto de la protesta social; pero sin lugar a dudas, las acciones más graves dentro de estos repertorios son los que implican daño físico a personas (civiles como agentes del Estado) e incluso la muerte. Es importante precisar que se considerará violencia política física sólo aquellas acciones que se enmarcan en el contexto de una protesta social, de lo contrario, se comprenderá como vandalismo o acciones delictuales.

La violencia represiva, por su parte, es la que se da de manera explícita y que va ligada con la privación de la libertad, la tortura, el maltrato, la mutilación o destrucción del cuerpo humano 
de su propiedad e incluso el asesinato político por parte de agentes del Estado en contra de personas miembros de la sociedad civil. Esta violencia se materializa a través de las fuerzas policiales y militares que el Estado tiene, mantiene y financia; y se puede dar a nivel macro (entre Estados), meso (hacia un grupo de la población en específico) y micro ${ }^{1}$ (hacia individuos); este estudio se concentrará precisamente en estos dos últimos tipos, ahondando en la meso.

Sin embargo, para esta investigación el foco de interés es la violencia represiva ejercida por el Estado en contra de la protesta social violenta y no violenta, y, por ende, la persecución y castigo físico a ciudadanos organizados que sostengan demandas políticas en un sistema democrático y cómo el Estado convierte la lucha social (al castigarla) en delitos para así criminalizarla y justificar la activación de la violencia represiva frente a la violencia física de la ciudadanía.

Lo anterior lo veremos a continuación en el análisis detallado de las relaciones que se dieron entre el gobierno del Presidente Lagos y el pueblo Mapuche. Se describirán los acercamientos y desencuentros entre ambos actores, los mecanismos de comunicación y las violencias que se practicaron a lo largo del sexenio de Ricardo Lagos.

\section{METODOLOGÍA}

Para poder observar los diversos tipos de repertorios de acción de manera comparativa y simultánea, se realizará un sencillo ejercicio que nos permitirá medir la intensidad del uso de la violencia entre ambos actores, tanto del Estado como de la población Mapuche.

Para lograr este objetivo, se realizó una revisión exhaustiva de la prensa nacional para registrar todos los acontecimientos a partir de marzo de 2000 a marzo de 2006, y luego clasificarlos de acuerdo a los resultados de la acción, no por intención, y así contraponerlas. Para corroborar esta observación se elaboraron dos escalas, una que mide la intensidad de las relaciones de violencia proveniente desde la sociedad civil y una proveniente desde el Estado. La primera de ellas es la proveniente desde la sociedad civil y que se ejerce en contra de la propiedad privada de grandes terratenientes y forestales principalmente, pero también en contra del Estado.

Esta primera escala está elaborada sobre cinco niveles, los que representan la intensidad de la violencia ejercida, siendo en escala ascendente el número 1 el menos violento y el número 5 el más violento. Bajo este mismo criterio se estratifican los repertorios de protesta de la sociedad civil, las prácticas de violencia que se ejercen, que van a acompañadas de una columna

1. Categorización propuesta por Johan Galtung (2004), que si bien no la relaciona con la violencia represiva del Estado, sino que más bien la utiliza para explicar los niveles de violencia, se utilizan las categorías porque parece pertinente al estudio. 
a la derecha que especifica a qué categoría de violencia pertenecen estas prácticas (simbólica o física $)^{2}$.

Estas escalas se utilizarán para medir eventos o hechos concretos que han sido registrados en la prensa nacional, como por ejemplo: el 5 de abril se registró una marcha pacífica en la ciudad de Temuco por parte de las comunidades Mapuche de la Araucanía y eso cabe en la categoría 1 en cuanto a repertorio de protesta y práctica de violencia, por lo que se encasilla en la categoría de violencia simbólica.

Se pensará la violencia política proveniente desde la sociedad civil en contra del Estado como una relación dual, con el objeto de abandonar la idea de que la violencia corresponde a un fenómeno exclusivamente estructural por parte del Estado. Se la entenderá como una forma de relación que se encuentra en permanente construcción y cambio, como un conjunto de dinámicas e interacciones, donde la sociedad civil se presenta como un agente capaz de propiciar la trasformación dentro de las estructuras estatales y económicas.

Tabla 1. Intensidad de las relaciones de violencia proveniente desde la sociedad civil $^{3}$

\begin{tabular}{|c|c|c|c|}
\hline Intensidad & $\begin{array}{l}\text { Repertorio } \\
\text { de protesta }\end{array}$ & Práctica & $\begin{array}{l}\text { Tipos de } \\
\text { violencia }\end{array}$ \\
\hline 1 & $\begin{array}{l}\text { Declaración pública, } \\
\text { marchas }\end{array}$ & $\begin{array}{l}\text { Protesta callejera, marchas, declaraciones } \\
\text { públicas, discurso desafiante y subversivo }\end{array}$ & $\begin{array}{l}\text { Violencia } \\
\text { simbólica }\end{array}$ \\
\hline 2 & $\begin{array}{l}\text { Toma de espacios pú- } \\
\text { blicos y privados }\end{array}$ & $\begin{array}{l}\text { Toma de espacios, toma de propiedad pri- } \\
\text { vada y pública }\end{array}$ & $\begin{array}{l}\text { Violencia } \\
\text { simbólica }\end{array}$ \\
\hline 3 & Daño a la propiedad & $\begin{array}{l}\text { Daño a la propiedad, esto se refiere no sólo } \\
\text { a construcciones, sino también a bienes } \\
\text { como camiones, maderas, maquinaria }\end{array}$ & Violencia física \\
\hline 4 & Enfrentamientos & $\begin{array}{l}\text { Daño a las personas, específicamente le- } \\
\text { siones menores }\end{array}$ & Violencia física \\
\hline 5 & Supresión de la vida & Supresión de la vida & Violencia física \\
\hline
\end{tabular}

Fuente: elaboración propia.

2. Es importante precisar que la ausencia de la violencia estructural en este actor no tiene la capacidad de ejercerla, sino que más bien la sufre. La violencia que puede ejercer la sociedad civil tiene un carácter de agencia, la capacidad de transformar las estructuras y así eliminar la violencia estructural a la que se encuentra sometido.

3. En este punto se observaran los resultados de los eventos, no las intenciones, ya que en muchas ocasiones las intenciones son, por ejemplo, una marcha pacífica, pero que termina en enfrentamientos con Carabineros, dejando algunos lesionados leves. Por lo tanto, lo relevante es el resultado de la acción y la intención primaria. 
La segunda escala que se elaboró es la que mide la intensidad de violencia proveniente del Estado en contra de la sociedad civil. Al igual que la escala anterior, la intensidad de la violencia tiene cinco niveles o rangos de intensidad, donde el número 1 es uno es la más baja intensidad de violencia y el número cinco la más alta.

Para el caso del Estado se establecieron dos columnas que agrupaban las categorías de violencia. La primera columna contiene las prácticas de violencia estructural, las que están directamente vinculadas con la utilización de los instrumentos legales disponibles para perseguir y criminalizar la protesta social. Esta columna también incluye prácticas de violencia simbólica ejercidas por el Estado en contra la sociedad civil.

La asociación entre estos dos tipos de violencia en una sola columna es en gran medida porque el ejercicio de violencia estructural -como por ejemplo la aplicación de la Ley Antiterroristatiene un gran contenido simbólico, ya que el discurso oficial que se configura en torno a los procesados está relacionado con la construcción de la idea según la cual las personas involucradas en estos hechos se han convertido en enemigos del Estado y de la ciudadanía en general, presentándolos como una amenaza real para la sociedad.

La segunda columna contiene todas las prácticas de violencia física que ejerce el Estado en contra de la sociedad civil. La violencia física ejercida por el Estado será denominada como violencia represiva, apelando a los términos y categorías ya existentes para este tipo de prácticas.

Tabla 2. Intensidad de las relaciones de violencia proveniente desde el Estado

\begin{tabular}{|c|c|c|}
\hline Intensidad & Práctica & Tipos de violencia \\
\hline 1 & Represión: disuasión, persecución y represión callejera, detención & Violencia represiva \\
\hline 2 & $\begin{array}{l}\text { Detención con procesamiento penal (criminalización de la } \\
\text { lucha social) }\end{array}$ & $\begin{array}{l}\text { Violencia represiva y } \\
\text { violencia simbólica }\end{array}$ \\
\hline 3 & $\begin{array}{l}\text { Lesiones físicas, allanamientos con violencia, interrogatorios fuera } \\
\text { de juicio, daños a la propiedad y a la personas }\end{array}$ & Violencia represiva \\
\hline 4 & $\begin{array}{l}\text { Criminalización de la lucha social a través de procesamiento espe- } \\
\text { cial: justicia militar, ley de seguridad interior del Estado y antiterrorista }{ }^{4}\end{array}$ & $\begin{array}{l}\text { Violencia represiva y } \\
\text { violencia simbólica }\end{array}$ \\
\hline 5 & Supresión de la vida & Violencia represiva \\
\hline
\end{tabular}

Fuente: elaboración propia.

4. Si bien es cierto todas las anteriores implican una violación a los derechos humanos, los números 3, 4 y 5 serán considerados como los de mayor importancia ya que ninguna de estas acciones pueden justificarse en contextos democráticos ante la protesta social bajo el concepto de la protección de la gobernabilidad política o preservación del Estado de Derecho 
Las categorías y escalas de medición serán las que por medio de eventos registrados permitirán medir la intensidad de la violencia política ejercida por cada uno de estos actores. Las escalas de la sociedad civil y el Estado, al tener los mismos rangos (cinco), permitirán cruzar la información y ver cuáles son los factores que activan o desincentivan el uso de la violencia política y cuál de las violencias es más recurrente.

Por ejemplo, si la convocatoria a una marcha pacífica Mapuche termina en graves enfrentamientos con Carabineros, dejando personas heridas, este hecho se clasifica en el nivel 4 de intensidad. Si bien los niveles 1 y 2 implican una violación flagrante a los derechos humanos, los números 3 , 4 y 5 serán considerados como los de mayor importancia, ya que ninguna de estas acciones puede justificarse en contextos democráticos ante la protesta social bajo el concepto de la protección de la gobernabilidad política o preservación del Estado de derecho.

Tabla 3. Escala de intensidad de violencia política

\begin{tabular}{|c|c|c|}
\hline Intensidad & $\begin{array}{c}\text { Violencia proveniente } \\
\text { desde el pueblo mapuche }\end{array}$ & Violencia proveniente desde el Estado \\
\hline 1 & $\begin{array}{l}\text { Protesta callejera, marchas, declaraciones } \\
\text { públicas, discurso desafiante y subversivo }\end{array}$ & $\begin{array}{l}\text { Represión: disuasión, persecución y re- } \\
\text { presión callejera, detención }\end{array}$ \\
\hline 2 & $\begin{array}{l}\text { Toma de espacios, toma de propiedad pri- } \\
\text { vada y pública }\end{array}$ & $\begin{array}{l}\text { Detención con procesamiento penal } \\
\text { (criminalización de la lucha social) }\end{array}$ \\
\hline 3 & $\begin{array}{l}\text { Daño a la propiedad, esto se refiere no sólo } \\
\text { a construcciones, sino también a bienes } \\
\text { como camiones, maderas y maquinaria }\end{array}$ & $\begin{array}{l}\text { Lesiones físicas, allanamientos con vio- } \\
\text { lencia, interrogatorios fuera de juicio, } \\
\text { daños a la propiedad y a la personas }\end{array}$ \\
\hline 4 & $\begin{array}{l}\text { Daño a las personas, específicamente le- } \\
\text { siones menores }\end{array}$ & $\begin{array}{l}\text { Criminalización de la lucha social a tra- } \\
\text { vés de procesamiento especial: justicia } \\
\text { militar, ley de seguridad interior del Es- } \\
\text { tado y antiterrorista }\end{array}$ \\
\hline 5 & Supresión de la vida & Supresión de la vida \\
\hline
\end{tabular}

Fuente: elaboración propia.

\section{Gobierno de Ricardo Lagos y el pueblo Mapuche}

Ricardo Lagos Escobar asume la presidencia de Chile en el año 2000, con la responsabilidad sobre sus hombros de ser el primer presidente de izquierda y socialista en llegar al Palacio de la Moneda tras el derrocamiento de Salvador Allende. 
Con un discurso altamente progresista, Ricardo Lagos aseguraba que Chile ya había superado el período de la transición a la democracia y que esta se había consolidado de manera exitosa. La llegada de Ricardo Lagos a La Moneda coincidió también con un renacimiento de los sectores de izquierda en Sudamérica, que comenzaron nuevamente a acceder al poder político después de varias décadas de ausencia obligada.

El clima en esta parte del continente era optimista, ya que se esperaba que esta reemergencia de la izquierda, renovada y progresista, podría llegar a imprimir los cambios estructurales que reorientaran las perspectivas neoliberales que estaban dominando el escenario regional y así reposicionar el tema social tan necesario en los países de la zona.

Ricardo Lagos, tal como lo hizo toda la nueva izquierda latinoamericana, incorporó en su agenda de gobierno el tema indígena, poniendo real énfasis en la situación Mapuche. Realizó una serie de promesas antes de asumir la presidencia y durante sus primeros meses de gobierno, lo que fue considerado positivo por las comunidades Mapuche en conflicto.

Se pensó que con Lagos la situación no podía ser peor que lo que fue durante la administración Frei. Se creía que la situación cambiaría con respecto a la relación con los pueblos originarios. Mal que mal, Lagos no era empresario ni conservador como Frei Ruiz-Tagle, además venía de una tradición socialista, activo en la lucha contra la dictadura militar, gran defensor de los derechos humanos y un líder 'democrático' y no cuestionado dentro de la Concertación de Partidos por la Democracia. Lagos asumía un nuevo gobierno e incluso muchos lo comparaban con Salvador Allende (Seguel, 2007, p. 102).

Consciente de las altas expectativas del pueblo Mapuche, el Presidente Lagos decide constituir una comisión para elaborar el Informe de Verdad Histórica y Nuevo Trato para los Pueblos Indígenas chilenos (Comisión Verdad Histórica y Nuevo Trato, 2003). Esta comisión buscaba un reconocimiento de los errores, abusos, excesos e impunidad de parte del Estado sobre ellos.

Este mea culpa provendría desde las diferentes partes de la sociedad chilena (Gobierno, expertos en el tema, académicos, comuneros Mapuche, Iglesia y agricultores) y se asumiría el despojo del territorio del que había sido víctima el pueblo Mapuche y la poca o nula intención del Estado de proteger sus derechos de propiedad.

El objetivo de solicitar y elaborar este informe era impulsar fuertes cambios en beneficio de la población indígena enfocados en la restitución de derechos y dignidad de su gente como pueblo. Los resultados arrojados por esta comisión permitieron exponer y reconocer la situación de extrema pobreza y abandono en que se encuentra la población Mapuche, en especial la rural. 
Tras casi tres años de trabajo, en donde no participaron todas las organizaciones Mapuche debido a que muchas de ellas se restaron a participar producto de problemas de forma y fondo en el desarrollo de su trabajo, el día 28 de octubre de 2003 la Comisión de Verdad Histórica dio a conocer su informe final. En lo central éste reconoció una larga historia de frustraciones y desarraigos para el pueblo Mapuche. Sin embargo, no se pronunció en lo absoluto sobre las complejidades del conflicto Mapuche actual (Álvarez y Pairicán, 2011, p. 20).

El resultado de los informes trajo como consecuencia la creación de un programa especial denominado "Orígenes". Este, sin embargo, no implicó un aumento sustantivo en la compra de tierras para las comunidades, ni una mejora en la situación de pobreza de los Mapuche.

El trabajo del Presidente Lagos frente a la cuestión Mapuche se enmarca en un nuevo proceso de asistencialismo e integracionismo, que potencia la homogeneización y chilenización de los Mapuche, dejando de lado los intereses autonomistas y reivindicativos de este pueblo.

Sin embargo, este "nuevo trato" hacia los pueblos originarios y en especial hacia el pueblo Mapuche se condicionó a la lealtad y afiliación de las comunidades hacia el gobierno del Presidente Lagos. Las organizaciones Mapuche o comunidades que se encontraban en conflicto, movilizadas a través de la protesta social, recibieron un trato diferente por parte del gobierno: violencia, persecución, criminalización y el encarcelamiento de los líderes y miembros de las comunidades, tal como se verá a continuación.

\section{Violencia política estatal contra la protesta social Mapuche}

La relación crítica entre el Estado y los grupos Mapuche que cuestionaban duramente el modelo de desarrollo económico que se estaba desarrollando en el país y principalmente en territorio Mapuche, ya se había presentado durante el gobierno del Presidente Frei, pero tomó ribetes inesperados en el gobierno de Ricardo Lagos.

A estas alturas, el despojo que había sufrido el pueblo Mapuche propició el surgimiento de una nueva militancia que configuraba una lógica de protesta, discurso y accionar de gran potencia. Este movimiento, con importantes características de insurgencia, fue uno de los más importantes y visibles durante todo el gobierno del Presidente Lagos por la Coordinadora de Comunidades en Conflicto Arauco Malleco.

La CAM, sin lugar a dudas, encabezó la fase ascendente de movilización del pueblo Mapuche en Chile en los últimos 15 años y representa un hito y un parteaguas en las reivindicaciones etnopolíticas y en las formas de acción colectiva tanto por su radicalidad y complejidad, por un lado, así como por su abierto proceso de conflictividad frente al Estado chileno, por el otro (Pineda, 2012, p. 44). 
La protesta social Mapuche fue inmediatamente perseguida. La presión y compromiso adquirido por Lagos con los grandes intereses económicos lo obligaban a escuchar y responder a las exigencias de los poderes fácticos y pasar por alto las soluciones propuestas por la Comisión y los tratados internacionales vigentes.

El presidente Ricardo Lagos decidió darle al conflicto un tratamiento judicial, descontextualizando los hechos de violencia, anulando la validez del derecho a la protesta, para enmarcarlos como actos criminales. Por lo anterior es que se decide implementar la reforma procesal penal en la región de La Araucanía como plan piloto.

Con estas medidas es que el Estado decide dejar en manos de la justicia un problema político, desentendiéndose así de su responsabilidad y condenando la protesta social Mapuche, invalidando el derecho a la desobediencia social, invisivilizando aún más el conflicto sociopolítico y etnoterritorial para convertirlo en un tema criminal.

El objetivo era sencillamente hacer respetar el Estado de derecho, asegurar la estabilidad política, pero principalmente mantener la confianza del empresariado asegurándoles que su productividad no sería afectada como consecuencia de estos episodios. Así se convirtió el conflicto social en un problema de seguridad del Estado que se pretendió solucionar a través de la persecución penal contra el Mapuche, utilizando leyes especiales creadas durante la dictadura, como la Ley 18.314, conocida como Ley Antiterrorista.

El Gobierno de Ricardo Lagos patrocinó 38 querellas criminales contra comuneros Mapuche, ya sea por los delitos de incendio, robo, lesiones graves, asociación ilícita terrorista, daños, lesiones, incendio terrorista, desórdenes calificados, usurpación, amenazas y tumulto; todas ellas ordenadas desde el Ministerio del Interior, en ese entonces a cargo del militante socialista y actual Secretario General de la OEA, José Miguel Insulza (Mella, 2012, p. 81).

Además, el Estado condicionó la negociación y compra de terrenos a las comunidades que aceptaron las condiciones impuestas por el Gobierno, advirtiendo así que todos aquellos grupos que desearan reivindicar por ellos mismos sus territorios, quedarían sin posibilidad de adquirirlos de manera legal.

Con respecto a los actos de mayor violencia registrados en las protestas de los Mapuche, se encuentran el daño a la propiedad privada, materializada en la quema de camiones forestales cargados de madera, quema de casas patronales y bodegas propiedad de los grandes agricultores o empresas forestales.

La CAM lideró el movimiento de recuperaciones de tierras contra propietarios privados y corporaciones forestales en esta etapa; realizó numerosas acciones que ellos denominan de 
"autodefensa" con la quema de maquinaria, insumos e instalaciones de dichos actores; finalmente, reivindicó un proyecto de "liberación nacional Mapuche", es decir, un proceso de reconstitución nacional (Pineda, 2012, p. 44).

\section{Análisis de los datos}

El año 2000 es de mucha actividad en términos de cantidad e intensidad de la protesta Mapuche. Durante los últimos meses del año se concentra el mayor número de acciones, y son siempre de nivel 1 y 3 de intensidad, a las que el Estado respondió con el nivel 4 de intensidad de violencia, criminalizando la protesta.

La violencia aplicada por el Estado siempre supera a la practicada por los Mapuche. Durante el año 2000 se registraron un total cinco enfrentamientos por parte de los Mapuche que terminaron con daños y lesiones menores a personas no miembros de la etnia. Fueron cinco actos de violencia contra la propiedad privada, 13 tomas de espacios privados y solo 17 declaraciones o discursos desafiantes, reflejando que a pesar de lo que se dice son más los hechos de violencia simbólica que la violencia física.

El Estado, por su parte, ejecutó cinco eventos de criminalización de la protesta, 17 allanamientos con violencia, 10 detenciones con procesamientos penales, y 4 eventos de represión callejera. La cantidad de allanamientos evidencia claramente cómo el Estado chileno y la Justicia deciden identificar a las organizaciones Mapuche radicalizadas como verdaderos enemigos del Estado. La violencia emanada de los allanamientos busca minar, desarticular y desintegrar las organizaciones y comunidades Mapuche en conflicto.

Tal como se muestra el gráfico 1, la violencia proveniente del Estado procura siempre estar un nivel más arriba que la proveniente de la sociedad civil. Es importante recordar que la violencia proveniente del Estado se entenderá como: 1) represión: disuasión, persecución y represión callejera, y detención; 2) detención con procesamiento penal (criminalización de la lucha social ); 3) lesiones físicas, allanamientos con violencia, interrogatorios fuera de juicio, daños a la propiedad y a la personas; 4) criminalización de la lucha social a través de procesamientos especiales: justicia militar, ley de seguridad interior del Estado y antiterrorista; 5) supresión de la vida.

Por otro lado, la violencia proveniente del pueblo Mapuche será descrita así: 1) protesta callejera, marchas, declaraciones públicas, discurso desafiante y subversivo; 2) toma de espacios, toma de propiedad privada y pública; 3) daño a la propiedad, referida no sólo a construcciones, sino también a bienes como camiones, maderas, maquinaria, etc.; 4) daño a las personas, específicamente lesiones menores; 5) supresión de la vida. 


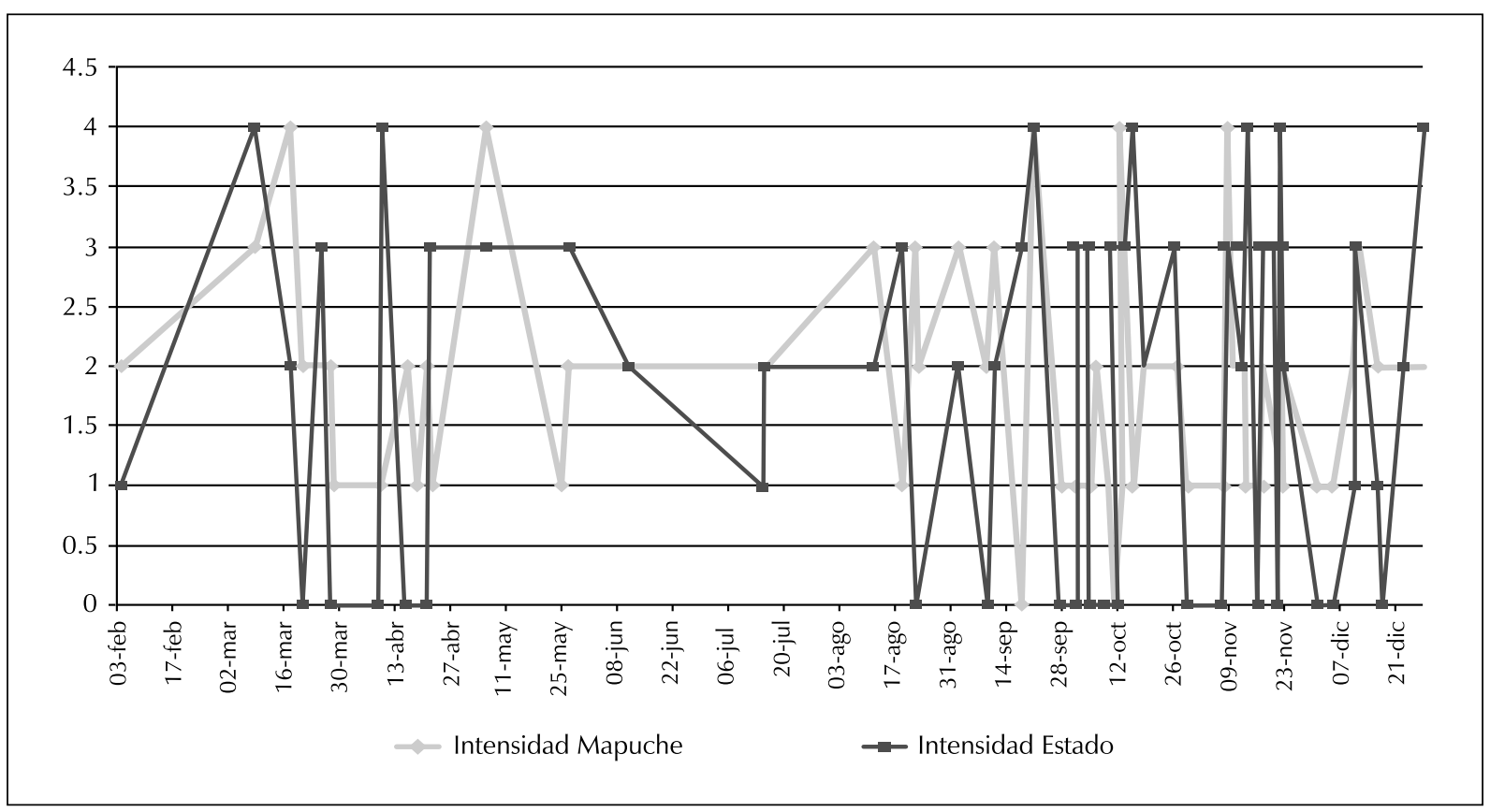

Gráfico 1. Intensidad de las relaciones de violencia del Estado chileno y el pueblo mapuche año 2000 Fuente: elaboración propia

El año 2001 comienza con una intensidad inusitada. La práctica predominante de violencia política por parte de la población Mapuche es nuevamente el daño a la propiedad privada y, como contraparte, el Estado responde aplicando la Ley Antiterrorista a todos estos casos.

Asimismo, los enfrentamientos que aparecen registrados en las gráficas como prácticas realizadas por la población Mapuche, se dan en la mayoría de las ocasiones por ambas partes, lo que quiere decir que son realizados tanto por los Mapuche como por los propietarios de los predios y como respuesta represiva por parte de los Carabineros (policía militarizada) a las ocupaciones ilegales. En ninguna ocasión estos enfrentamientos han sido provocados unilateralmente por parte de los Mapuche.

En síntesis, la persecución penal se transforma del ejercicio de una facultad estatal, en una estrategia para perseguir a quienes enarbolan demandas sociales y políticas legítimas dentro de un Estado social de derecho (Gonzáles, Mella, Lillo, 2007, p. 67).

Hacia finales del año 2001, el 13 de diciembre para ser exactos, la fiscalía de Traiguén recibe una llamada telefónica por parte de Juan Agustín Figueroa Elgueta, administrador del fundo Nancahue, denunciando (denuncia No. 1275) un incendio forestal de pino insigne en la zona. El fiscal de zona fue al sitio del siniestro y constató los hechos en la resolución 009 
(con fecha 12/12/2000), planteando la hipótesis de que el incendio podría haber sido producto de acciones coordinadas de comuneros Mapuche no identificados.

Al día siguiente los Loncos ${ }^{5}$ Pascual Pichún y Aniceto Norín fueron encarcelados y acusados de amenaza de incendio terrorista, dando inicio al emblemático Caso Loncos, caso que fue fuertemente cuestionado por la fragilidad de las pruebas que condenaron a cinco años y un día de prisión a los involucrados.

El Estado chileno, las forestales, las grandes transnacionales, los gobernadores e intendencias se hicieron parte en todo... nos condenaron presentando 120 testigos. Yo estuve un año y cinco meses encarcelado y después gané el juicio con 120 testigos en mi contra, ninguno apuntaba a los hechos y yo salí. Entonces anularon el juicio para poder condenarme. Se reanuda el juicio y no demoró más de nueve meses y estaba más malo el segundo juicio que el primero. Pusieron pruebas, testigos clave que tampoco pudieron decir la verdad, decían que era un grupo beligerante (Norín, 2010).

Siete días más tarde se produce un nuevo incendio forestal, esta vez en el predio Poluco Pidenco, dando inicio a un nuevo caso emblemático en la lucha por la recuperación territorial comandado por la CAM. En esta ocasión se acusó a comuneros de las localidades de Tricauco, San Ramón y Chekenko de ser responsables de los hechos, pero estos negaron su autoría.

Con el fin de erradicar de raíz estos hechos de violencia, la gobernación provincial de Malleco decide liderar este proceso y presentar una demanda en contra de los autores, cómplices, encubridores y cualquiera que resultase responsable de incendio, robos con violencia, lesiones, usurpación en el grado de tentativa y otros delitos.

Lo relevante de este punto es que los daños a la propiedad pública no fueron procesados bajo esta ley especial, sino que única y exclusivamente se utilizó para proteger y condenar el ataque al patrimonio particular de grandes agricultores y de las empresas forestales, lo que marca un claro indicio de que los intereses que se estaban resguardando eran los de los grandes poderes económicos.

La utilización de la Ley Antiterrorista dio un mayor margen de acción a los fiscales en su investigación, pero también permitió ampliar las condenas a los procesados. Además, esto permitió que los acusados fueran procesados simultáneamente por la justicia militar, lo que terminaba por duplicar las condenas.

5. Locos se refiere a la máxima autoridad dentro de una comunidad mapuche en tiempos de paz. El lonco es un líder tradicional que organiza la vida política de la comunidad. 
Esto facultó a la fiscalía a procesar un sinnúmero de órdenes de allanamientos extremadamente violentos, acompañados de tortura, interrogatorios sin orden, intimidación y violencia física. Estos allanamientos tenían como objetivo buscar y encontrar a los culpables de dichos atentados. El objetivo de estas prácticas consistía en difundir el terror entre los comuneros Mapuche, para así poder conseguir testimonios incriminatorios.

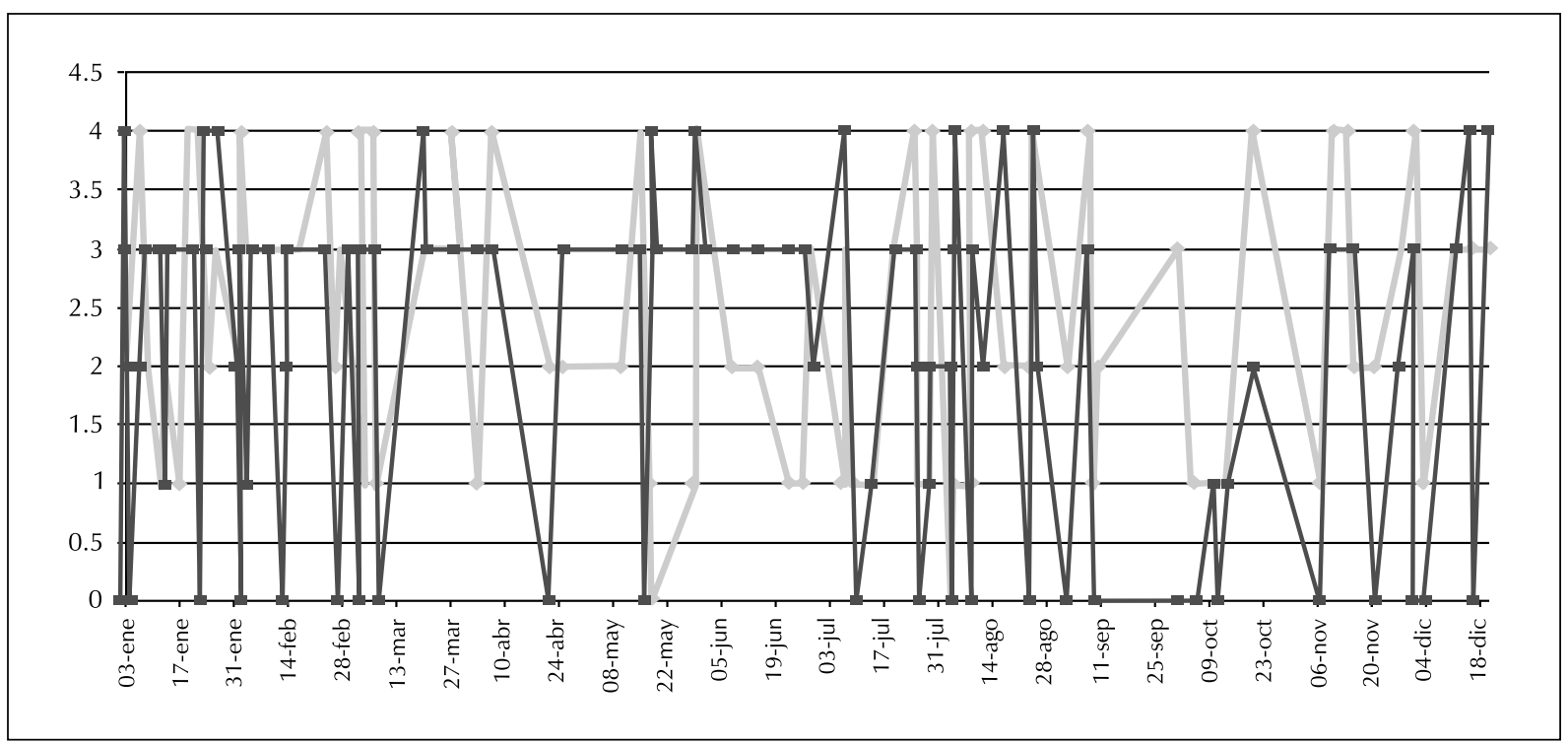

Gráfico 2. Intensidad de las relaciones de violencia del Estado chileno y el pueblo mapuche año 2001 Fuente: elaboración propia

El año 2002 comenzó agitado para la población Mapuche, ya que el 21 de enero la empresa forestal Mininco presentó una querella criminal y solicitó que el Ministerio Público investigara los delitos de robo con violencia e incendio de bosques, dando paso a la Operación Paciencia, dirigida desde la Subsecretaría del Interior, que sindicó y persiguió a la Coordinadora de Comunidades en Conflicto Arauco Malleco (CAM) como una organización de carácter terrorista.

Durante el gobierno de Lagos se persiguió selectivamente a un grupo Mapuche que conformaba esta organización, como responsables de conformar una banda terrorista. Esta fue, sin duda, la acción que provocó mayor impacto ante la prensa, los órganos públicos y las organizaciones de derechos humanos, porque vulneró el derecho a la libre asociación (González, Mella y Lillo, 2007, p. 67).

Esta es una prueba irrefutable de que la democracia chilena se consolidó mayoritariamente en el ámbito institucional, pero que en la práctica estaba disponible sólo para algunos ciudadanos, 
no para la mayoría. La persecución y encarcelamiento selectivo de ciertas asociaciones Mapuche, calificadas como ilícitas y terroristas, demuestra que la democracia chilena está muy lejos de estar consolidada, ya que la oposición, disidencia e insurgencia política es duramente perseguida y condenada.

Los escasos espacios para manifestar demandas sociales, disidencia política y disconformidad en Chile son extremadamente limitados, por lo que la protesta social se convierte en un canal válido, pero no legitimado por la sociedad y el Estado, para visibilizar estas situaciones de crisis. La protesta social es fuertemente reprimida por la policía, porque presenta un riesgo de quiebre para el orden social y político.

El descontrol del uso de la violencia del Estado en contra de la protesta Mapuche llegó a su punto más álgido en enero de 2002 cuando durante una ocupación-recuperación de tierras en el fundo Santa Alicia en la comuna de Ercilla, provincia de Malleco, el joven comunero Alex Lemún perdió la vida por la acción de los Carabineros. Este asesinato quedó sin procesamiento judicial, en total impunidad y con completo respaldo del Ejecutivo.

A partir del asesinato de Lemún comenzó una represión nunca antes vista en contra del movimiento Mapuche. En diciembre de 2002, luego de una sigilosa operación de inteligencia destinada a la desarticulación del movimiento denominada Operación Paciencia, se llevaron a cabo detenciones masivas en contra de dirigentes y comuneros Mapuche en las provincias de Arauco, Malleco y Cautín. A los detenidos se les formalizó por asociación ilícita terrorista y se sumó otra demanda por incendio terrorista imputando a los Loncos de Didaico y Temulemu, y el caso conocido como Poluco Pidenco, también caratulado de terrorista y por el cual se formalizó a once Mapuche pertenecientes a las comunidades de Tricauco, San Ramón, Chequenco y Rucañanco (Mella, 2012, p. 82).

Por lo tanto, se puede afirmar que el asesinato del joven comunero en manos de los aparatos represivos del Estado en un contexto de protesta social fue el parte aguas entre el Estado y el pueblo Mapuche. Al Gobierno de Lagos no le quedó más alternativa que apoyar las acciones de los Carabineros y de los fiscales, con el objetivo de sostener hasta las últimas consecuencias el argumento de que se estaba persiguiendo a criminales y terroristas. Para los Mapuche, por otra parte, este acontecimiento implicó cerrar las puertas al dialogo y la negociación con el Estado y declararlo su enemigo.

La bullada democracia chilena que pretendía consolidar el Presidente denominado por todos como el Gran Estadista, Ricardo Lagos, en su segundo año de gobierno comenzó a 'hacer agua' cuando se hablaba y recordaba el conflicto Mapuche. El tratamiento de este conflicto fue políticamente incorrecto e inconsecuente con lo que se había planteado y buscado en la comisión que se encontraba trabajando. 
La falta de democracia para la libre asociación, libre expresión y para el ejercicio de la protesta social, demuestra que Chile y sus gobernantes no estaban preparados para enfrentar el conflicto social que promueve cambios en las estructuras y aperturas en temas de participación.

Durante los primeros cuatro meses del año 2003, todos los hechos acontecidos se vincularon a la detención de comuneros Mapuche acusados de ser los autores de los atentados incendiarios ocurridos durante el año 2002. De ese modo, transcurrido más de un año de los hechos y de la presentación de las querellas del Caso Puluco Pidenco, el día 14 de enero de 2003 comienzan las diligencias por parte del Ministerio Público y la policía que dan como resultado la detención de numerosos Mapuche, en su mayoría dirigentes de comunidades del sector de Ercilla, donde cuatro importantes dirigentes Mapuche quedan en prisión preventiva acusados de asociación ilícita terrorista. Se les acusa de robo con violencia e incendio de bosques e infracción de la Ley 18.324 que sanciona conductas terroristas. El 16 de enero de 2003 solicitan la detención de seis Mapuche como autores de incendio de carácter terrorista. Cuatro comuneros fueron condenados a diez años y un día de prisión por incendio terrorista, dando fin a la Operación Paciencia y al Caso Puluco Pidenco.

Con esto, el Estado chileno desarticuló y descabezó a la dirigencia de la activa y radical Coordinadora Arauco Malleco, impulsando a los pocos dirigentes que no habían sido apresados a pasar a la clandestinidad.

La región de La Araucanía comenzó a vivir un fuerte proceso de militarización y acoso policial (allanamientos, torturas, persecución, etcétera). Esta violencia instalada se puede explicar porque el Estado chileno es más neoliberal que democrático.

Después de la muerte del joven Alex Lemún, la contención de la protesta social por medio de la represión directa se hizo insostenible. Las investigaciones judiciales en contra de dirigentes Mapuche cobraron mayor protagonismo.

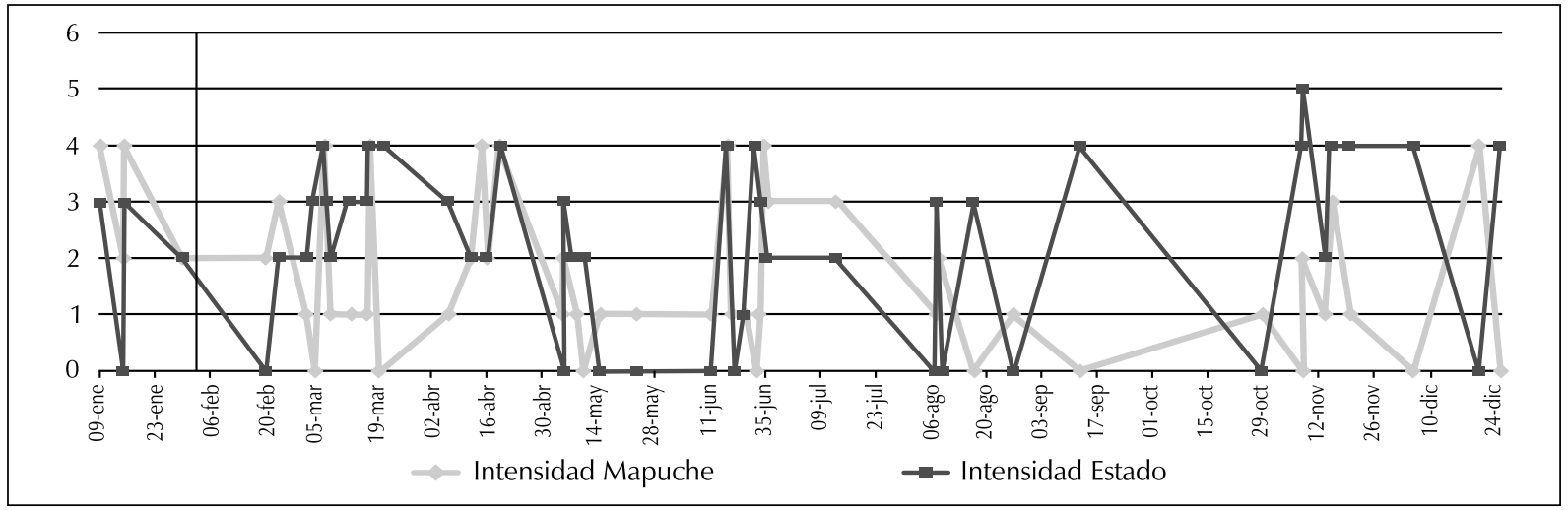

Gráfico 3. Intensidad de las relaciones de violencia del Estado chileno y el pueblo mapuche, año 2002 Fuente: elaboración propia 
Es ahí donde adquiere relevancia la actuación de la policía, que va a cumplir labores tanto de inteligencia como de la ejecución de órdenes judiciales, que la autorizan para allanar sedes de organizaciones, casas de dirigentes Mapuche y detener personas (González, Mella y Lillo, 2007, p. 69).

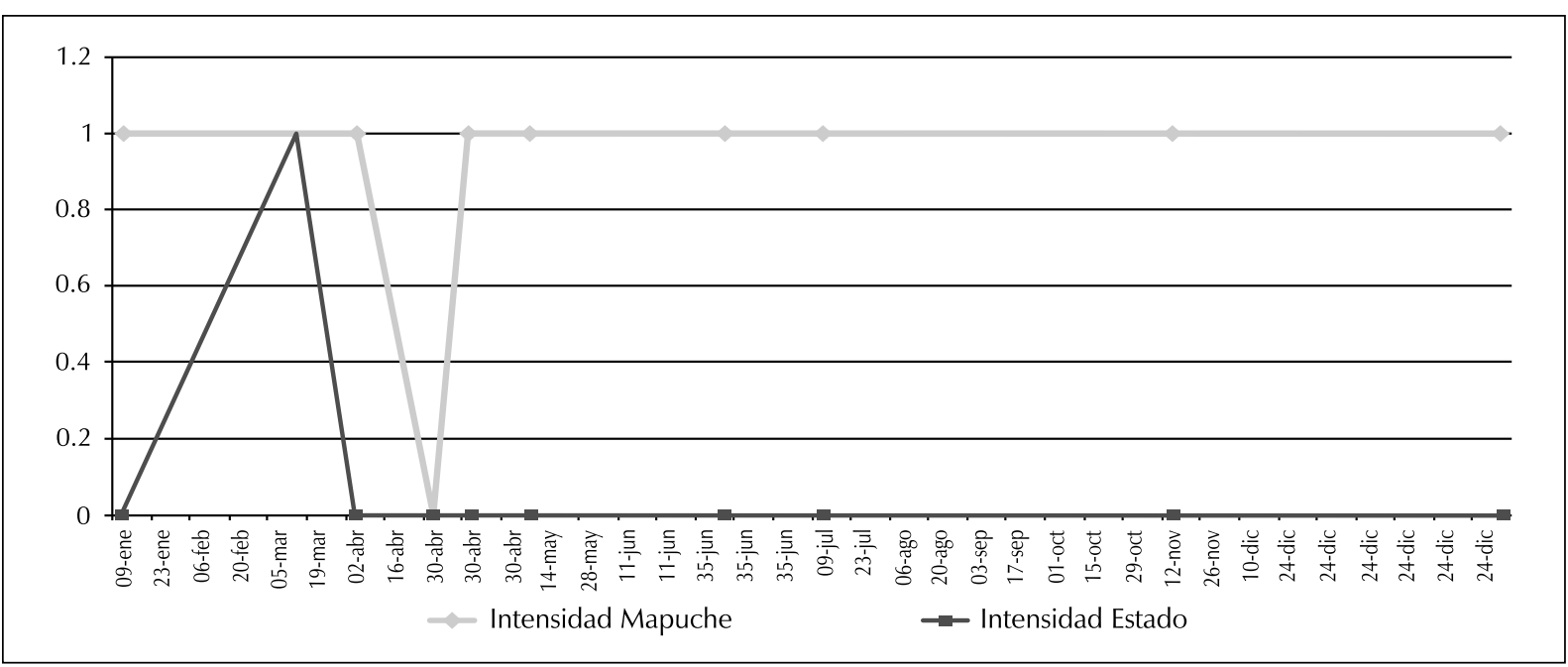

Gráfico 4. Intensidad de las relaciones de violencia del Estado chileno y el pueblo Mapuche, año 2003 Fuente: elaboración propia

Además de lo anterior, el Estado comenzó a proporcionar servicios de seguridad a las grandes empresas y agricultores que estaban siendo atacados por la población Mapuche, a través del respaldo policial. Además permitió que se abastecieran de seguridad privada armada y que persiguieran a los presuntos implicados en los hechos de violencia. Los Trizano es uno de estos grupos y estaba compuesto por ex agentes del Centro Nacional de Inteligencia de la dictadura militar.

Lo relevante son todos los procesamientos que se efectuaron en contra de la población Mapuche durante el gobierno de Ricardo Lagos: se persiguieron sólo los hechos de violencia en contra de la propiedad privada de los grandes empresarios, pero no de ciudadanos en contra de chilenos.

La violencia que imprimen los Mapuche en su protesta se orienta principalmente al reproche del sistema de producción de las grandes forestales sobre la propiedad usurpada.

Durante los procesos de recuperación territorial se han dado enfrentamientos en donde las fuerzas policiales irrumpen con armamento de guerra, siguiendo los procedimientos ordenados. Se muestra así que la violencia ejercida por el Estado es mucho mayor que la de los supuestos terroristas Mapuche, quienes no han cobrado la vida de ningún civil ni mucho menos de agentes del Estado. 
El problema de toda esta situación es la inconsistencia e incongruencia de los gobiernos de la Concertación, en particular del presidente Ricardo Lagos, quien no había dudado en decir: "invito a los pueblos indígenas a ocupar espacios que les pertenecen en nuestra democracia y a ejercer a plenitud los derechos que esta democracia garantiza" (Lagos, 2003), pero cuando esto sucedió tampoco dudó en exigir una persecución penal en contra de los implicados, sus familias, comunidades y etnia en general, criminalizándola, condenándola y estigmatizándola.

Una situación que no pudo garantizar el nuevo sistema de justicia fue el derecho a un debido proceso, ya que hizo uso de la Ley Antiterrorista para procesar y condenar a los involucrados en casos de protesta social violenta en contra de la propiedad privada, como si se hubiese atentado en contra de la vida de personas. Así, la "consolidación de la democracia chilena" que anunció Lagos se inauguró con la violación reiterada de los derechos humanos de la población Mapuche.

Ello también se contradice tristemente con el esfuerzo que tuvo que hacer el país entero para la elaboración del Informe Valech donde se registraban, denunciaban y reparaban económicamente todas los casos de violación a los derechos humanos ocurridos durante la dictadura, situación que se contradecía abiertamente con los hechos de violaciones de todo tipo de derechos en contra del pueblo Mapuche por parte de los gobiernos democráticos.

Aparentemente, para el Presidente Lagos las únicas personas que merecerían ser respetadas, reparadas y reintegradas a la sociedad tras la violación a sus derechos humanos son las que sufrieron represión bajo la dictadura militar. Por supuesto, dentro de su informe no incluyó las violaciones a los derechos humanos y asesinato que se cometieron contra la población Mapuche en su propio gobierno.

El gobierno de Lagos sintetiza la paradoja que vivió el pueblo Mapuche con los gobiernos de la Concertación, ya que a pesar de la existencia de un discurso incluyente, en la práctica se registraron distintas formas de represión. El Presidente Lagos fue uno de los grandes defensores y encubridores de los empresarios madereros y de la devastación ecológica que se estaba produciendo en las regiones del sur del Chile. Además fue el que dio paso a la persecución penal bajo la figura de terrorismo aplicada a los militantes Mapuche que protestaban violentamente en contra de la invasión territorial, consignándose durante este período los tres casos más emblemáticos de esta lucha.

Por lo tanto, la reaparición de la izquierda chilena en el poder político implicó una fuerte decepción en términos políticos y económicos para algunos sectores de la sociedad, ya que los avances en términos de apertura democrática fueron escuetos y las reformas estructurales en el ámbito económico excesivamente limitadas. El gobierno de Ricardo Lagos se perpetuó como la nueva izquierda chilena fuertemente neoliberal.

El año 2004 se destacó por la gran cantidad de denuncias de irregularidades en los juicios que condenaban a los dirigentes Mapuche bajo la Ley Antiterrorista. Estas denuncias fueron 
expuestas por los abogados defensores, comunidades y líderes encarcelados, las que se confirmaron cuando la Corte de Apelaciones desestimó abiertamente el veredicto del tribunal local que absolvía a los imputados del Caso Loncos y rectificó el veredicto para otorgar la condena.

En este contexto judicial, para nadie era un misterio que la suerte estaba prácticamente echada para los imputados del caso Asociación Ilícita Terrorista, más aún si los condenados por el caso Poluco Podenco y los Loncos de Traiguén, también eran imputados en esta causa, es decir, varias personas fueron juzgadas en más de un proceso judicial por el mismo delito (Mella, 2012, p. 84).

Esto trajo como consecuencia una serie de manifestaciones de protesta por parte de las comunidades miembros de la organización, las que expresaron su disconformidad con los veredictos y con la criminalización de la protesta con más ocupaciones simbólicas y recuperaciones territoriales, las que con frecuencia terminaban en enfrentamientos con los Carabineros. Debido a estos enfrentamientos, los tribunales decidieron dar la orden a la policía de realizar guardias dentro de los fundos militarizando las comunidades.

Durante el año 2004 se puede ver cómo la protección de los derechos de propiedad de los grandes poderes económicos son más importantes en la democracia chilena, que el derecho a un juicio justo y el respeto por los derechos humanos de sus ciudadanos comunes, como los Mapuche.

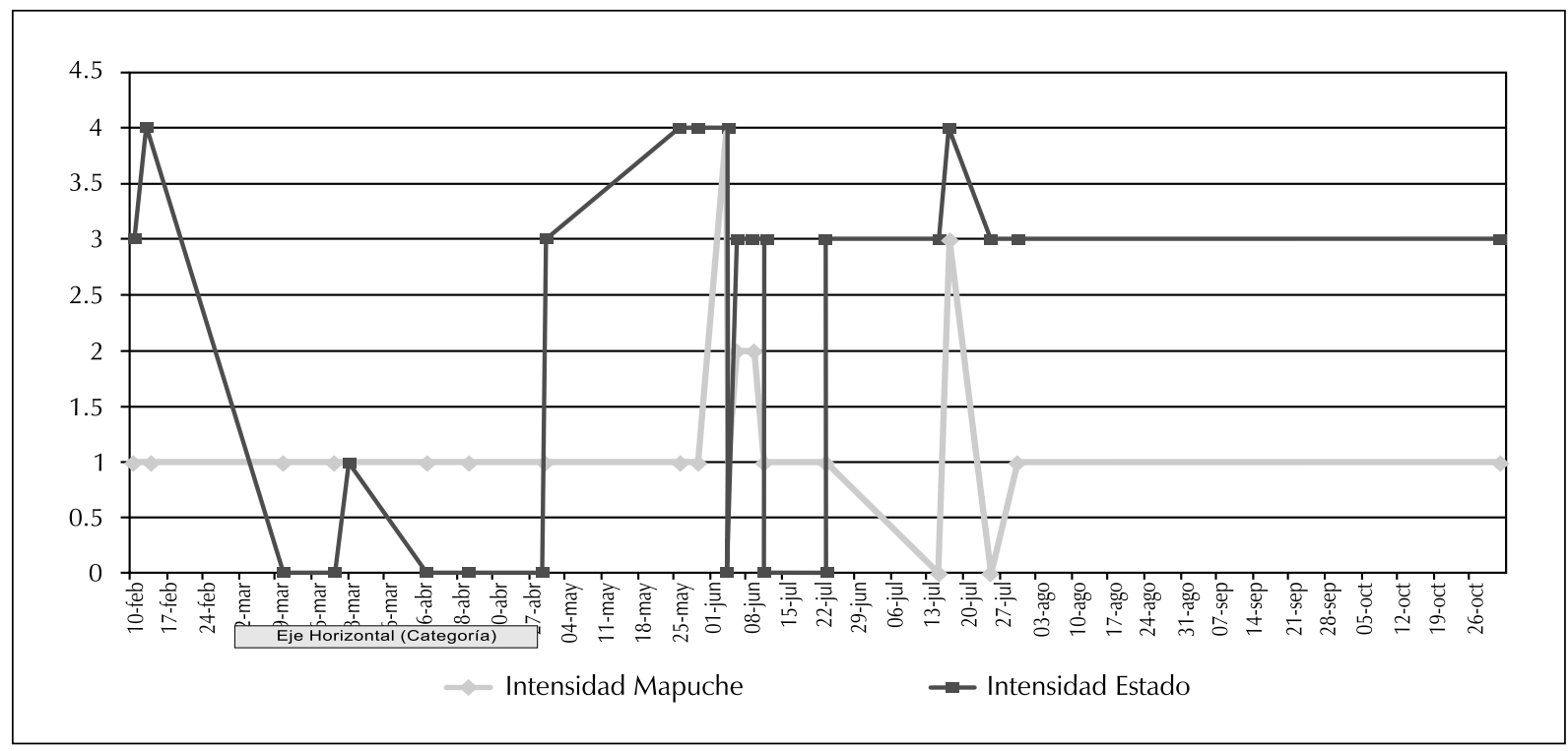

Gráfico 5. Intensidad de las relaciones de violencia del Estado chileno y el pueblo mapuche, año 2004 Fuente: elaboración propia 
La reiterada violación a los derechos humanos por parte del Estado chileno en el gobierno de Ricardo Lagos deja en evidencia que el legado autoritario y represivo de la dictadura no era una prioridad para erradicar. El gobierno de Lagos no dudó en consentir prácticas abusivas en contra del pueblo Mapuche, por lo que se puede afirmar que la democracia y la justicia en Chile son temas selectivos para ciertos grupos de chilenos como se puede constatar en los hechos recién presentados.

Las pocas garantías que proporciona la justicia chilena a los ciudadanos comunes, se demuestra una vez más al estudiar el caso Mapuche. Es claro que el sistema de justicia se modernizó no con el fin de democratizar y ampliar los derechos de democracia e igualdad para los chilenos, sino que los cambios buscaban proteger el modelo neoliberal de mercado y los intereses económicos de los grandes empresarios.

El año 2005 hay una considerable baja en la intensidad de la protesta Mapuche, la que sólo se movió en el ámbito de lo simbólico, ya que se concentró en denuncias y declaraciones sobre el excesivo número de allanamientos en contra de su población, y en la violencia que los acompañaban.

El agotamiento de las comunidades y sus liderazgos frente a la represión del gobierno parecía estar surtiendo efecto, ya que el decaimiento en el activismo vinculado a la recuperación territorial se hace evidente.

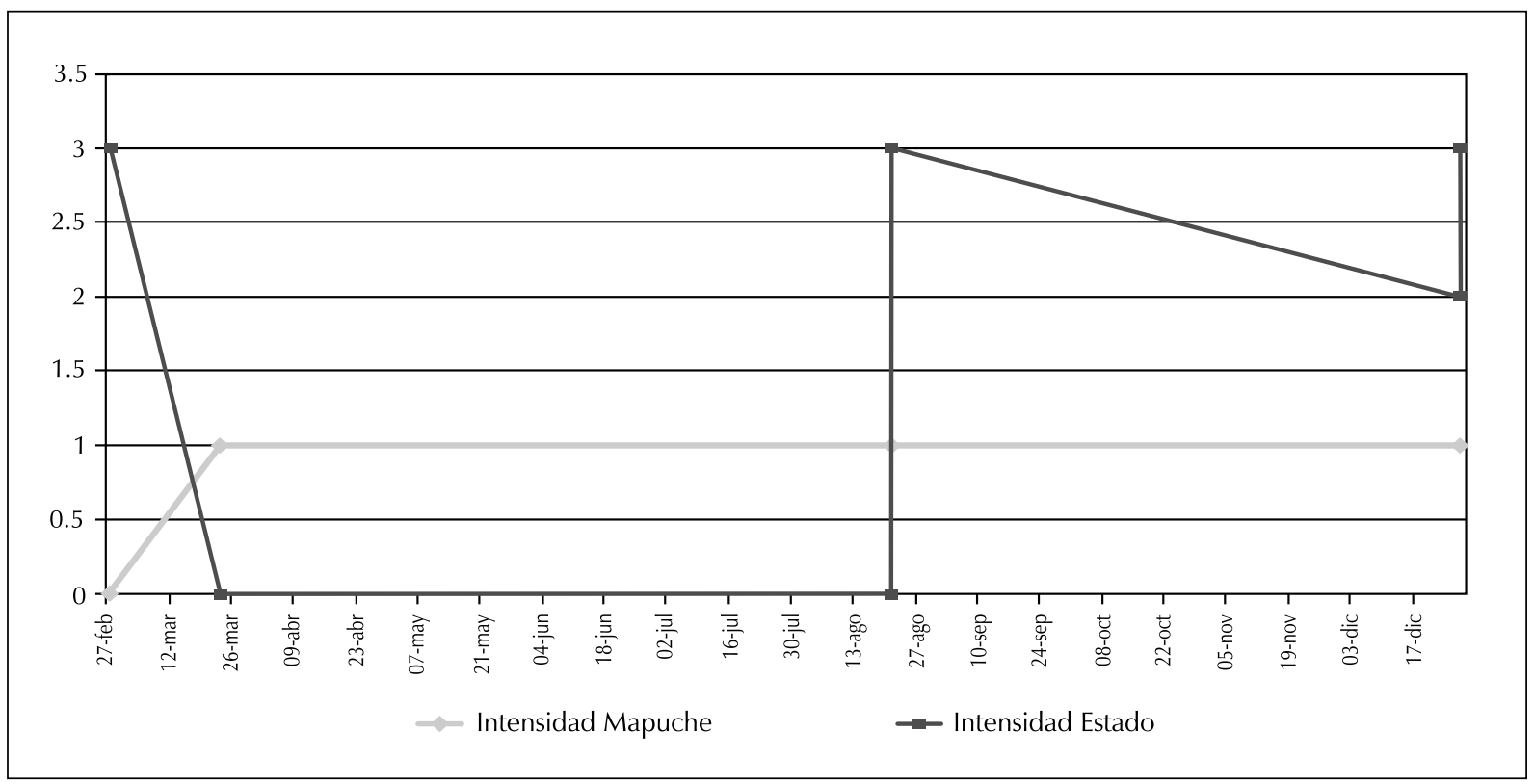

Gráfico 6. Intensidad de violencia del Estado chileno y el pueblo mapuche, año 2005

Fuente: elaboración propia 
La estrategia de desgaste producto de la violencia utilizada por el Gobierno del Presidente Lagos fue muy similar a la que se usó durante la dictadura. La persecución selectiva, intimidación, amedrentamiento, tortura y asesinato han formado una nueva generación completa de Mapuche, que a pesar de que nacieron y crecieron en un sistema democrático, sólo conocen a través de la violencia política.

La violencia estructural que ejerce el Estado chileno ha logrado traspasar y permear la cultura política del país, al punto de que se mantiene constante, independiente del régimen político, de los dirigentes que asumen el poder o la coyuntura ideológica que lo rodea. Chile es un país donde la disidencia política, la protesta social o la insurgencia ciudadana, son vistas como verdaderas amenazas al discurso hegemónico de la política chilena, vinculada al orden irrestricto y las preservación de las estructuras político-económicas reinantes, en vez de convertirse en grandes oportunidades de cambios y aperturas democráticas.

\section{CONCLUSIONES}

El gobierno del presidente Lagos sintetiza la paradoja que vivió el pueblo Mapuche con los gobiernos de la Concertación, ya que a pesar de la existencia de un discurso incluyente, en la práctica se registraron distintas formas más vinculadas a la asimilación y chilenización que al reconocimiento y respeto por el otro.

La criminalización y persecución de la protesta Mapuche en torno a sus demandas etnopolíticas durante todos los gobiernos de la Concertación, pero en particular en el gobierno del Presidente Lagos, deja en evidencia la gran distancia que existe entre el discurso progresista y lo fáctico.

Existía la esperanza de que el retorno de la izquierda al poder, nueva, renovada y llena de los aprendizajes del pasado, fuese capaz de romper con la tradición de utilizar la violencia y represión como instrumento de resolución de conflictos sociales. Por el contrario, el Presidente Lagos queda recordado como uno de los grandes defensores y encubridores de los empresarios y poderes fácticos.

El apoyo incansable de su Gobierno a los empresarios madereros, de celulosa y pesquera que invaden territorio Mapuche y aceleran la devastación ecológica en las regiones del sur del Chile, da testimoniado en el conflicto Mapuche.

Aunado a lo anterior, la llegada de los gobiernos socialistas democráticos implicó para la población Mapuche el inicio formal de la persecución penal bajo la figura de terroristas, la que fue aplicada a sus dirigentes, militantes y simpatizantes Mapuche que protestaban violentamente en contra de la invasión territorial y violación a los derechos de la que estaban siendo víctima. 
Esta criminalización política tuvo dos consecuencias: la primera de ellas es que se generaron grandes divisiones dentro del pueblo Mapuche en términos externos (a nivel etnia) e internos (a nivel de la organización). La segunda consecuencia es que se educaron nuevas generaciones completas de Mapuche en la doctrina e ideología del mapuchismo y la resistencia, pero también bajo un fuerte y estricto régimen de represión y violencia que ha radicalizado y fortalecido sus ideales de liberación.

En lo que se refiere al impacto externo que generó esta criminalización, se puede afirmar que el Estado consiguió crear una imagen clara de que existen Mapuche buenos y malos, imagen que se potenció, difundió e instauró gracias al apoyo y trabajo de los medios de comunicación que polemizaban, sobredimensionaban y descontextualizan las acciones de protesta de los Mapuche.

Esta categorización de terroristas generó gran impacto en la ciudadanía, que sumida en la ignorancia, optó por apoyar las acciones del Estado con el fin de terminar con la insurgencia Mapuche que atentaba directamente con la estabilidad de la democracia y la confianza internacional de los inversionistas extranjeros. Esta idea fue planteada en reiteradas ocasiones por el poder económico y la prensa nacional.

Esta situación implicó, a su vez, que en el ámbito interno se generaran grandes rupturas, donde los 'Mapuche buenos' inculpaban, acusaban, apuntaban y denunciaban a los 'Mapuche malos', con el objetivo de conseguir los privilegios que el Estado ofreció: restitución de territorio y recursos para trabajarlo, como también evitar verse envueltos en juicios, encarcelamientos, allanamientos, episodios de violencia represiva y más discriminación de la que viven normalmente.

Asimismo, durante el gobierno del Presidente Lagos se pudo observar como la CAM fue la organización que con un discurso fuertemente articulado bajo la ideología mapuchista busca reivindicar y recuperar el patrimonio cultural, político y tradicional del pueblo Mapuche, como base fundamental para la reconstitución de su nación.

A pesar de que este discurso y repertorio de protesta era conocido por el mandatario Lagos, en su respuesta y accionar no demostró aprendizaje histórico, sino que, por el contrario, recurrió a la represión política y judicial, en vez de dar paso a nuevas formas democráticas de solución al conflicto social.

En este sentido, la lucha Mapuche es como haz de luz que permite ver el entramado del poder del capital y cómo éste ha logrado establecer fuertes alianzas con el poder político y con el Estado, independientemente de su ideología política, la que ha dado como resultado el saqueo de los recursos por medios de la extracción forestal, hidroeléctrica y celulosa.

Sumado a lo anterior, la protesta e insurgencia Mapuche es la punta de un iceberg que refleja cómo la ciudadanía chilena excluida de las formas de representación institucional y convencional, se vio en la obligación de forjar sus propios entramados políticos al interior de sus comunidades. 
Ellos crearon sus propios espacios de participación y discusión, ya que estos no estaban disponibles en el sistema, lo que les permitió constituir cuerpos organizados alternativos que politizaron ámbitos diversos del interés Mapuche y que después desplazaron a través de la protesta del ámbito privado de sus comunidades al público nacional generando gran impacto por sus coordinadas acciones de ocupación de espacios públicos, tanto físicos como discursivos.

Tal como lo hicieron y evidenciaron los Mapuche, diferentes grupos de la sociedad civil chilena se han visto en la obligación de articular e instituir sus propios cuerpos organizativos, para canalizar sus discusiones e intereses que les permite ejercer la democracia de manera paralela a la institucionalizada hasta ahora, para finalmente explotar en grandes movimientos, que parecen espontáneos, pero que cuentan con tiempos extensos de articulación, gestación y construcción del discurso.

Los niveles de violencia represiva, simbólica y estructural que se desencadenaron en contra de la protesta Mapuche durante los gobiernos de la nueva izquierda chilena de Ricardo Lagos y Michelle Bachelet, demuestran que estos gobiernos no consolidaron una democracia moderna e inclusiva. La razón para desarticular estas redes es que estas han puesto en evidencia la debilidad y falencias de la democracia chilena, la falta de espacios de participación e inclusión, los escasos canales de expresión y la represiva respuesta a las acciones insurreccionales ante el servilismo de la clase política hacia los grandes poderes económicos.

El uso de la violencia por parte del Estado a la hora de resolver conflictos sociopolíticos ha sido un elemento característico de la historia republicana chilena (Portales, 2010), principalmente porque está incorporado por el Estado como un instrumento de control social y de dominación, mecanismo que ha resultado exitoso para la conservación y concentración del poder político.

La violencia política por parte del Estado se encuentra, hasta cierto punto, legitimada y justificada a través del derecho y normas legales; pero también institucionalizada por medio de los aparatos represivos y militares del Estado, por lo que se puede decir que el Estado chileno es y actúa como:

Una asociación de dominación con carácter institucional que ha tratado, con éxito, de monopolizar dentro de un territorio la violencia física legítima como medio de dominación y que, con este fin ha reunido todos los medios materiales en manos de su dirigente y ha expropiado a todos los funcionarios estamentales que antes disponían de ellos por derecho propio, sustituyéndolos con sus propias jerarquías supremas (Weber, 1997, p. 92).

La institucionalización de estas formas de control social se concreta gracias al establecimiento de "la legitimidad basada en la 'legalidad", en la creencia en la validez de preceptos legales y en la 'competencia' objetiva fundada sobre normas racionalmente creadas" (Weber, 1997, p. 87). 
Por lo que el Estado crea leyes que facilitan la alienación y automatización de la población, cumpliendo así un rol restrictivo y supervisor de los ciudadanos, que busca establecer límites que terminan por acentuar la individualidad de estos, situación que conlleva a debilitar la sociedad civil como contrapeso natural del Estado, convirtiendo a este en un ente inaccesible y desvinculado de la sociedad y sus necesidades.

A pesar de que la violencia política estatal en Chile es parte de una tradición republicana (la que ha sido siempre justificada y disfrazada con la idea de civilidad ciudadana, gobernabilidad política y Estado de derecho), se esperaba que con la llegada de la nueva izquierda liderada por Ricardo Lagos se comenzara a materializar el aprendizaje que implicó superar una dictadura militar como la de Augusto Pinochet.

Se esperaba que con la nueva democracia chilena disminuyeran o desaparecieran estas prácticas a la hora de resolver los conflictos sociopolíticos, ya que se estaba dando paso a un nuevo momento en la historia de Chile, la del perdón, superación del pasado, modernización y progresismo político.

\section{BIBLIOGRAFÍA}

- Álvarez, R. (2001). Gran empresariado, poderes fácticos e imaginarios políticos. El caso de la transición democrática chilena (1990-2000).Texto inédito, Santiago de Chile 2010

- $\quad$ Arendt, H. (1970). Sobre la Violencia. México: Fondo de Cultura Económica.

- Berger, Lucio (2005). Entre el desierto verde y el país productivo. El modelo forestal en Uruguay y el Cono Sur, Amigos de la Tierra y la Casa Bertolt Brecht. Web: http://www.olca.cl/ oca/chile/region10/cisnes152

- Bengoa, J. (2007). Historia de un conflicto. Los Mapuche y el Estado nacional durante el siglo XX. Santiago: Editorial Plantea.

- $\quad$ Bengoa, J. (2000) Historia del pueblo Mapuche. Siglos XIX y XX. Santiago: Ediciones LOM.

- Bengoa, J. (1995). Breve Historia de la legislación indígena en Chile. En: Etnia y Nación en América Latina. México: Editorial Consejo Nacional para la Cultura y las Artes

- Bourdieu, P. (2000) La dominación masculina. Barcelona: Anagrama.

- $\quad$ Castañeda, J. (2006). Latin América's Left Turn. Foreign Affairs, 85 (3), 28-25. 
- Declaración de Principios suscrito por los Jefes de Estado y de Gobierno asistentes a la Segunda Cumbre de las Américas (1998). Recuperado de: http://www.summit-americas.org/ ii_summit/ii_summit_dec_sp.pdf

- Faúndez, J. J. (2004). Reformas a la Justicia en Chile y Criminalización de las Demandas Indígenas. Memorias del IV Congreso de la ed Latinoamericana de Antropología Jurídica (RELAJU). Quito.

- Galtung, J. (2004). Trascender y transformar. Un introducción al trabajo de conflictos. México: Editorial Quimera.

- Gómez Tarín, F. J. (2001). De la violencia física a la violencia simbólica. La estructura de la ficción y el poder. Valencia: Universidad de Valencia.

- Hernández, I. (2003). Autonomía o ciudadanía incompleta. El pueblo Mapuche en Chile y Argentina. Santiago: CEPAL.

- Informe de la Comisión verdad Histórica y Nueva trato con los Pueblos Indígenas (2008). Recuperado de: http://www.corteidh.or.cr/tablas/27374.pdf

- Kay, C. (2005). Violencia y regulación de conflictos en América Latina. En: Violencia y regulación de conflictos en América latina. Caracas: Nueva Sociedad.

- Lagos, R. (2005) en radio Cooperativa Ricardo Lagos: "Hemos logrado consolidar una democracia" Recuperado de: www.cooperativa.cl, 05 de octubre de 2005

- Le-bert, J. M. (2004). Informe final de evaluación Programa Orígenes Ministerio de Planificación y Cooperación. Recuperado de: http://www.dipres.gob.cl/574/articles14937_doc_pdf.

- Martínez, C. (2009). Comunidades y redes de participación Mapuche en el siglo XX. Nuevos actores étnicos, doble contingencia y esfera pública. En: Las disputas por la etnicidad en América latina: movilizaciones indígenas en Chipas y Araucanía. Ediciones Catalonia

- Mella, E. (2008). Criminalización de la protesta Mapuche. antecedentes históricos y sociales. Revista Reflexión, 36.

- Mella, E. (2012). El Estado chileno contra la protesta social, 2000-2010. Revista Sudhistoria, 4. Recuperado de: http://www.sudhistoria.cl

- Michaud, Y. (1989). Violencia y Política. Buenos Aires: Ediciones Sudamericana. 
- Pairicán, F. y Álvares, R. (2011). La nueva Guerra de Arauco: La Coordinadora AraucoMalleco y los nuevos movimientos de resistencia en el Chile de la Concertación (1997-2009). En: M. Modonesi y J. Rebón (comps.), Una década en movimiento. Luchas populares en América Latina en el amanecer del siglo XXI. Buenos Aires: Ediciones CLACSO.

- Pineda, C. (2012). Dominación y emancipación en el pueblo Mapuche. El pensamiento de la Coordinadora Arauco Malleco. Revista Sudhistoria, 4. Recuperado de: http:// www.sudhistoria.cl

- Schmitt, C. (1999). El concepto de lo político (texto de 1932), Texto de 1932 con un prólogo y tres corolarios. Madrid: Alianza, 1999.

- Sorel, G. (1971). Reflexiones sobre la Violencia. Buenos Aires: Ediciones Sur.

- Toledo LLancaqueo, V. (2006). Pueblo Mapuche. Derechos colectivos y territorio: desafíos para la sustentabilidad democrática. Santiago: Ediciones LOM.

- Villegas Días, M. (2009). El Pueblo Mapuche como enemigo del derecho (penal). Consideraciones desde la biopolítica y el derecho penal del enemigo. Publicaciones del Instituto de Derecho Penal Europeo e Internacional. Recuperado de: http://www.cienciaspenales.net/ descargas/idp_docs/doctrinas/Mapuche\%20actor\%20social\%20enemigo.

- Yañez, N., Aylwin, J. (eds.) (2007). El Gobierno de Lagos, los pueblos indígenas y el 'nuevo trato'. Paradojas de la democracia chilena. LOM Ediciones (libro completo consultado)

- Weber, M. (1997). El Político y el Científico. Madrid: Editorial Alianza. 